\title{
Chapter 10. Contending for Ritual Control of Land and Polity: Comparisons from the Timor Area of Eastern Indonesia
}

\author{
James J. Fox
}

\section{Defining a Focus}

The first task in this paper is to locate the problem at hand within a theoretical framework that identifies its significance. ${ }^{1}$ I begin with an examination of the idea of land and domain among the Rotinese. My specific focus is on the central domain (nusak) of Termanu on the island of Roti itself. Although there is considerable linguistic and cultural variation among the domains of the island, the Rotinese share a basic understanding about the nature of their domains. They have all been subjected to similar formative influences. Among the domains of Roti, Termanu was the domain selected by the Dutch East India Company to establish its strategic presence in the second half of the 17th century and, as a consequence, through much of the 18th and 19th centuries, it was politically and socially paramount in developments on the island.

Nearly one third of the Rotinese population now lives on the island of Timor, having begun migrating there in the early 19th century. Although the Rotinese have brought to Timor many ideas of identity based on the particular domain from which they originated, they have not formed new domains (nusak) on Timor. This fact is itself significant and suggests that the nusak was a particular historical formation. Such a formation could not be replicated culturally in the new conditions the Rotinese encountered on Timor in the 19th century.

Having considered Rotinese ideas of land and territory, I will extend my analysis to two societies on the island of Timor: the Atoni Pah Meto who are also known as the Dawan, the dominant population of West Timor, and the Tetun, particularly the southern Tetun, whose centre in Wehali is regarded by many Timorese as the ritual centre of the island. For purposes of comparison, I focus on the domain of Amanuban among the Atoni. This domain rose to considerable political prominence, particularly in the 19th century, when it successfully resisted Dutch colonial incursions into the mountains of West Timor. For the southern Tetun, I consider Wehali itself, whose ritual head was regarded by the Dutch as Kaiser (Keizer) and by the Portuguese as Emperor (Imperador) of the island of Timor. Wehali was the ritual centre of a network of tributary 
states, which the Dutch and Portuguese regarded as paramount to the political organisation of the island.

At the outset of this paper, it is important to note that land and territory in eastern Indonesia are oriented space. On Timor, this orientation is based on two primary axes: an east-west axis (in line with the 'path' of the sun) and another crosscutting axis, which is, depending on the lie of the land, generally north-south. Thus the 'head' of the land is to the east; the 'tail' to the west. These axes and the values associated with them are part of the origin structures of the societies of Timor and are implicit in the local understanding of origin narratives. What constitutes the idea of the 'centre', however, varies among these societies and is usually constructed by reference to the categories of up/down or inside/outside. Subtly but invariably, the centre is given either a 'male' or 'female' symbolic valency. Wehali insists on an emphatic self-definition as 'centre' and 'female.'

In the communicative context of eastern Indonesia, to focus on any category prompts consideration of the dyadic sets within which that category occurs. Critical knowledge in the societies of the region is invariably encoded in formal pairs of semantic terms whose relation to one another provides an understanding of the cultural sense of both terms. ${ }^{2}$ The ritual languages relied on to recount the most fundamental cultural knowledge are expressed in dyadic, profoundly poetic forms of speaking (see Fox 1988).

\section{Land and Domain on Roti}

The key terms to consider here are the Rotinese words dae (Proto-Austronesian *daReq), meaning variously 'earth', 'land' and 'territory', and nusa(k) (Proto-Austronesian, *nusa) which can be translated, in different contexts, as 'island', 'land' or 'domain'. I begin with an exegesis of the word dae.

In ordinary language, dae refers to the earth. In ritual language, dae, 'earth', pairs with batu, 'stone'. Thus the formal expression for the earth is dae bafak ma batu poin, 'Land's Mouth and Rock's Point', in contrast with the 'Heavens and Heights', poin do lain, and the 'Depths of the Sea', liun do sain. (Dae can also have the meaning of 'below' as in the phrase, ndia neme lain leo dae: 'it goes from above to below.)'

One can refer to the 'land of Roti' as dae Lote but Roti itself is described generally as a nusa, an 'island'. Thus Roti is simply Nusa Lote. Nusa, however, also forms the semantic basis for designating the named territories or domains (nusak) that form the local polities of the island: Nusak sanahulu falu lai nusa Lote a: 'There are eighteen domains (nusak) on the island (nusa) of Roti.'

Each nusak was headed by a ruler whose title was that of Manek or 'Male' Lord. Rule was centred on the site of the ruler's residence, which was designated as the nusak lain, the 'high domain'. The power of the ruler was based in, and 
emanated from, this 'high domain'. The ruler presided at a court in the 'high domain'. The symbolic ordering of this court centre was intended to reflect the state of the domain as a whole. In Rotinese, nusak thus denotes court and court centre as well as the domain as a whole (See Fox, in press a).

Each nusak \pm was composed of a number of leo. These leo are the clans or 'origin groups' of the domain. The existence of each leo was acknowledged by a position in the 'high domain', by representation at the Lord's court and by assignment of a role in the performances of the origin rituals of the domain. Each leo was thus represented at court by its own Mane Leo.

Leo, in turn, are generally divided into smaller named lineages or -teik ('wombs', 'stomachs'), which can be distinguished further into bobongik ('birth groups'). Houses (uma) are the basic units of Rotinese society but rarely encompass more than two generations. Unlike other societies in eastern Indonesia, there are no houses that represent an entire 'origin group/clan' (leo) or even an entire lineage (-teik). Clans make general claims to ancestral areas-different parts of a particular domain associated with ancestral actions or earlier historic residence - but ownership of productive land - fields, gardens, portions of an irrigated rice complex - is maintained at the level of the household (uma) or among closely related households that derive from the same immediate ancestor.

Marriage rules for the leo of Roti vary. In some domains of Roti, leo are strictly exogamous. In others, such as Termanu, small leo are generally exogamous, whereas large leo permit marriage among individual teik or lineages (see Fox 1979a for a comparison between the domains of Thie and Termanu).

Clans (leo) have no existence outside their particular nusak; hence, there is no system of island-wide clan connections nor any clan network that transcends a particular nusak. The rulers of different domains intermarried but each ruler retained his own dynastic line based on a distinct genealogical origin. Thus no form of comprehensive nobility emerged on Roti. The nusak established strict (physical) boundaries for definition of all origin groups.

In ritual language, nusa pairs with ingu, another term for 'land', 'territory', 'place of residence'. Thus one can refer to nusa no tola-non, ingu no ka'a-fadi: 'a domain of relatives, a land of lineage mates.' In some dialects of Rotinese, such as Bilba, the term ingu-lain is used with the same sense as nusak lain in the dialect of Termanu. Ingu, however, also forms a pair with leo, meaning 'clan's or 'origin group'. Ingu is also a common element in the name of various origin groups: Ingu-Beuk, Ingu-Fao, Ingu-Nau. There are thus, linguistically and culturally, close linkages between the concepts of nusa, ingu and leo. A key point that needs to be emphasised is the fact that there is no presumed size to any of these categories. Some nusak on Roti are large units, either in terms of land or population, and are comprised of many leo; others are much smaller and are only a fraction of the size of the larger nusak. 
In present-day Roti, members of different origin groups (leo) tend to cluster in different parts of a domain but the leo itself has lost most of its associations as a residential group. The origin narratives, however, describe the leo as if they were originally residential groupings: as separate small ingu or independent nusak that were, by conquest or deception, brought under the power of the high domain (nusak lain) of the ruler.

In Roti, residence is scattered. There are no discrete 'villages' and only limited evidence of a period when there might have been such discrete villages. The Rotinese terms for village are taduk or nggolok (nggolo-taduk), which imply a 'promontory' or headland. Generally, settlements are designated by specific names and names change as one moves through any particular settlement.

The existence of the various domains on Roti was acknowledged formally by a succession of contracts between their individual rulers and the Dutch East India Company beginning as early as 1662 (Fox 1971). As local polities, they continued to be recognised until 1968 when they were subsumed within the bureaucratic structures of the Indonesian Government. Warfare among these polities, especially over issues of land, continued well into the 19th century when the Dutch Colonial Government asserted the right to determine and maintain fixed borders between states. ${ }^{3}$

Each domain possesses its own narrative of the origin of the nusak, whose foundation and initial formation is regarded as having occurred before the arrival of the Europeans. The narratives provide an account of the ancestral foundation of the state, of the dynasty of its rulers and of the precedence and prerogatives of its origin groups. These state narratives, as told from the point of view of each ruling line, also recount the conquest, assimilation and absorption of other origin groups as the state expanded. This process of state incorporation allowed for the inclusion of other outsider groups within the domain.

\section{The Domain of Termanu}

Termanu was recognised by the Dutch East India Company as the foremost domain on Roti in 1662. ${ }^{4}$ It might already have been in the process of growth at the time of its recognition. Dutch recognition and the location of a small Dutch post on the coast of Termanu contributed to a period of expansion. In the 18th century, this expansion was curtailed and territory that Termanu appears to have subjugated was granted separation and returned to other rulers. Thus Termanu was initially advanced and then eventually disadvantaged by its relations with the Company. Because of these continuing relations, the archival records of developments in Termanu are particularly revealing.

Termanu possesses an elaborate oral history that is concerned primarily with the establishment and development of the domain. In the telling of the history of the domain, the first important narrative recounts a division of the domain 
between its ruler and a particular clan lord who holds the title of dae langak, Head of the Earth. In the narrative, the ancestor of what is to become the ruling clan of Termanu arrives in the domain and challenges the resident ancestor of the Head of Earth's clan to a series of contests, which he wins by cunning and deception. This narrative establishes a separation between political power on the one hand and ritual authority on the other. The narrative is an example of a common Austronesian political charter myth whereby an 'outsider' is installed 'inside' and thus granted the right of rule (Fox 1995; Sahlins 1985). According to this narrative,

the first person to settle in the territory (then known as Pada) was Pada Lalais. One day the ancestor of what was to become the ruling line of Termanu, Ma Bulan, wandered through Pada and met Pada Lalais. They immediately began to argue over who was first to arrive in Pada and agreed to test each other's claims by planting trees to see whose tree would flourish. Pada Lalais planted a quick-growing damar tree while Ma Bulan planted a slow-growing bubuni tree. After the trees were planted, however, Ma Bulan went back and switched the trees in each hole. When the two inspected the trees, the tree in Ma Bulan's hole was alive and well and he thereby claimed to be the winner. Pada Lalais would not accept this outcome so they agreed to have another contest.

This time, they vied with each other over who could call the sea. Ma Bulan knew the sea, having come from over the seas, whereas Pada Lalais had an autochthonous knowledge of the earth. Ma Bulan therefore told Pada Lalais to call the sea as the tide was about to go out. He called but the tide continued to recede. Ma Bulan then waited until the tide was about to come in; he then called the sea and it came to him. Thus Ma Bulan was able to claim victory in the second contest.

The two then agreed to have a third contest by examining each others's houses to see whose showed signs of being older. Ma Bulan immediately rethatched his house with eucalyptus leaves and then lit a fire that quickly turned the eucalyptus thatch soot-black. When the two ancestors came to inspect each other's houses, Pada Lalais' lontar leaf thatch was not as black as the eucalyptus thatch of Ma Bulan's house. Ma Bulan once more claimed victory.

In the end, Ma Bulan, who had demonstrated the deceptive cleverness required of a ruler, offered the following solution to divide their functions. Thus he made the following proposal: 'It would be good if I became Lord and you became Head of the Earth for succeeding generations. When men have filled this domain, I will rule them and you may levy a tribute on the domain and take a portion of lontar syrup from 
each person who lives in the domain. And for all times, since you were the first to settle in this domain, this domain will be given the name Pada, in keeping with your name, Pada Lalais, and your grandchildren and descendants.

The narrative of this ancestral division of land and polity ends, however, with an additional narrative observation based on a folk etymological link between the personal name of a later ruler and the name of the domain. This is recounted as follows:

In the time of Lord Tolamanu Amalo, a descendant of Ma Bulan, the company asked Tolamanu: 'What is the name of your domain?' So Tolamanu said: 'It is called Tolamanu in recognition of my name.' So it was called Termanu but the name Pada did not disappear. The domain is called by both names, Pada and Termanu, to the present time.

The chief elements of this narrative consist of: 1) the arrival of the stranger from the sea; 2) a set of contests between the stranger and the indigenous inhabitant; 3) the eventual installation of the stranger as ruler; and 4) a division of the realm in which the indigenous inhabitants retain rights over the earth. The displacement that occurs in this narrative is regarded as irreversible. Ritual authority over the land or earth is vested in a particular clan within the domain, whose priority of residence is acknowledged but whose precedence is superseded by that of the ruler.

Termanu is not alone in possessing a narrative account of similar opposition between an outside ruler and indigenous ancestral group. Each domain has its own narrative recounting the origins of this opposition - which, in some cases, amounts to implacable enmity - between ruler and 'head of the earth'. In some domains, such as Thie, this basic structure is more complicated: the function of 'head of the earth' is vested in one clan but various rights to harvest produce are disbursed among several clans associated with the 'head of the earth' (see Fox 1980b: 120-5).

Several critical points are important to note here. Dual structures occur at different levels in different societies in eastern Indonesia. On Roti, the primary diarchy in relation to the earth occurs at the foundation of the nusak. The nusak thus locates the rituals of the earth and sets a boundary to their functioning. No rituals of the earth extend beyond the boundaries of the nusak. All nusak have this primary diarchy, which may well be the most critical feature of a nusak.

A nusak as a structural entity is expandable. In line with the oral narratives, a Manek can incorporate the ingu/leo of another manek within his realm and bring the individual rituals of those incorporated ingu/leo into the cycle of his own rituals. 
The significance of these features of Rotinese society should become apparent in a comparative analysis of other societies in eastern Indonesia.

\section{Comparison with the Atoni Pah Meto of Timor}

The Atoni are a large and distinct ethnic population of more than 750,000 people, who inhabit more than two-thirds of West Timor. They refer to themselves as the 'people of the dry land' (atoni pah meto). Land (pah) is primary in their definition of themselves and in a great number of Atoni titles: Atau-pah, Ana'-pah, Afen-pah, Abain-pah. Like the Rotinese, they have a long history of European contact. They have been subject to longer and more intensive contact than the Rotinese with both the Portuguese and the Dutch. Their political formations date back to a period well before the coming of the Europeans (Fox 1988) and although there are similar patterns of political structure among the Atoni states or domains, differences among these states are greater than among Rotinese domains. For the purpose of this paper, I draw comparisons between Termanu, the largest domain on Roti and Amanuban, the domain that became the dominant Atoni state in West Timor for a significant period during the 18th and the 19th centuries.

One of the chief differences between the Rotinese and the Atoni is in the structures of their origin groups. Atoni origin groups are known as kanaf. Each kanaf designates a named clan group, all members of which bear the same name. Members of a kanaf claim the same origin and are said to derive from the same source, whose site is (or is regarded as) a physical location. A kanaf is predominantly exogamous in that most members marry with members of other kanaf but it is possible for 'female' lines to form within local settlements and for 'male' lines of the same kanaf within these settlements to marry with these 'female' lines (Fox 1999).

'Houses' (ume, uem) are important social units but, as on Roti, there are no houses that represent an entire kanaf. Houses represent members of a kanaf at the level of the local settlement. Settlements (kuan > Tetun, knua > PAN/PMP *banua) are significant not as ordered space but as a local ordering of precedence among particular kanaf.

A recurrent theme in Atoni narratives is the need for land: Pahat maklen leuf, nifu maklen leuf: 'Land too limited, water too limited.' This quest for land has scattered members of the different kanaf throughout West Timor. The expansion of kanaf, as related from the perspective of any one kanaf, is described as a journey of a single being or a single name. These narratives, recounted in ritual language, describe the significant encounters of the kanaf in its passage through the Timorese landscape.

States among the Atoni are seen as a coming together of a cluster of kanaf as a single domain. The recurrent formula for this clustering is always that of a 
group of four lords (usif), four 'fathers', each representing a separate kanaf, subject to and thus supporting a single lord (usif) of a ruling kanaf. The pattern is recursive. The domain can be built up of circles of four clans. Any lesser lord can also order groups around him in a cluster of four.

The demographic strength of a kanaf and its authority as a ruling kanaf may be confined to a single domain; yet members of most kanaf are not confined to a single domain but can be found in many domains. Thus, unlike Roti, kanaf identity transcends the boundaries of any domain or state.

Any domain is an 'ordering' of the land. Thus, for example, the great ruler of Amanuban was known by the personal title Ta mes pah: 'We Unify the Land' (see Schulte Nordholt 1971: 310), or Ek pah: 'To Enclose the Land' (McWilliam 1989: 39).

Among the Atoni, anyone who claims local authority can be called a pah tuaf, 'lord of the land'. The title has many of the connotations of that of dae langak on Roti. For example, a pah tuaf generally has the right to claim harvest tribute.

\section{The Domain of Amanuban}

There are a variety of versions of the narrative of the founding of Amanuban. Here I will summarise the narrative account told by the late Raja of Amanuban, K. Nope, to A.D.M. Parera (1971: 127-9). The narrative links the ancestor of the ruling line of Amanuban to Roti and its traditions.

According to this narrative, the ancestors of the Nope and Isu lines came from Roti. After spending some time in Kupang, these ancestors became goat herders for Lord Abineno in Oekabiti. At the time, each night a goat would disappear. Ancestor Nope therefore took up guard at night and discovered that a great snake with a shining jewel in its head was stealing the animals. He and Isu stole the jewel and fled from Oekabiti with their treasure along the southern coast of Timor to a place at Tun'am in Amanatun. There they met the ancestors of Nitbani and Nomleni to whom they became wife-takers in return for a tribute of the harvest. This arrangement failed and so the two ancestors left Amanatun and moved on to Tunbesi in Amanuban where Tenis and Nubatonis were lords of the land (pah tuaf). Nope and Isu assisted Tenis and Nubatonis in trading sandalwood.

In time, these ancestors quarrelled over who was to become Raja and they agreed to resolve the issue by various contests. The first contest involved the planting of a banana tree that had been cut in two. Tenis and Nubatonis planted the tip of the banana, which failed to take root and grow; Nope, however, planted the base of the banana, which grew. The second contest involved the planting of sugar cane. This time Tenis 
and Nubatonis planted the base of the sugar cane while Nope planted the tip. Again, Nope's plant grew. In their third contest, the ancestors lit torches to see which one would burn longest. Tenis and Nubatonis' torch went out during the night when it became damp with dew. Instead of burning his torch, Nope took the jewel he had taken from the great snake and placed it into his torch. This jewel shone through the night until dawn. Thus Nope became ruler using both the name of Nope and that of Nuban (from Nubatonis). He elevated Isu and Fina as his male lords and Saé and Bako as his female lords, with Sole, Nome, Nabuasa and Teflopo as his meo-warriors. This created the first structure of the domain of Amanuban. Nope was installed at the centre of the domain surrounded by circles in groups consisting of four lords with different functions.

This narrative has various parallels with the foundation narrative for the domain of Termanu. Nope is an 'outsider' who triumphs over the local lords of the land by a series of contests, supplants these lords, and installs himself at the centre the domain. In analogous founding charters, the new lord drives out the previous lords of the land. Here, as is the case in Termanu, the previous 'heads of the earth/land' remain as subordinate lords in the domain.

As with the Rotinese narrative, the name of the domain is considered crucial. In Roti, the compact between the two ancestors initially establishes the name of the domain as Pada, after the head of the earth. Only later is the ruler's name adopted as a second name. In the Amanuban narrative, there is a similar compromise. The ruler takes two names, one of which is that of the lord of the land. In effect, therefore, the domain retains the name, Nuban (Ama-Nuban: 'Father(s) - Nuban') of the supplanted lord of the land. As in the Termanu narrative, the Amanuban contest between the ancestors determines precedence among the constituent clans of the domain. The ordering of the domain follows the recurrent formula of four lords around a centre with a second group of lords (meo $=$ warrior lords) around these inner lords.

\section{The Tetun of Timor}

Analysis of Tetun society requires an investigation like that directed to Atoni society. The Tetun are a large group who straddle both sides of the East/West Timor border. In West Timor, the Tetun are divided into a northern (foho: 'mountain') and a southern (fehan: 'coastal') group. The northern group reckons relations within its origin groups through males; the southern group reckons its origins through its women. The coastal Tetun also extend across the border into East Timor and another group of Tetun is located in the central south of the territory as well. There are more than 400,000 Tetun who speak the Tetun language as a first language. (Others in East Timor have adopted a simplified 
dialect of the language as a lingua franca, which is on its way to becoming the national language of the country.)

This paper will concentrate on the coastal Tetun of West Timor and, more specifically, on the Tetun of Wehali. Wehali is regarded as the sacred centre (laran) of the entire Tetun population. Wehali is considered rai feto, 'female land', as opposed to rai mane, 'male land', and is the traditional site of the Maromak Oan, 'The Child of the Luminous', who is also described as the Nai Bot, 'The Great Lord', or Nai Kukun, 'The Dark Lord'. The authority of this lord was once acknowledged through the presentation of harvest offerings from groups from a large area of Timor, including many of the domains of the Atoni themselves.

Wehali's authority still encompasses a wide area that acknowledges Wehali as its centre. According to its origin myth, Wehali is a great banyan tree that offers shade to its constituent groups. The ordering of its groups follows a fourfold division. Wehali itself is known as the Rai Lidun Hat, Rai Sikun Hat: 'Four Corner Land, Four Section Land.'

In linguistic terms, the Tetun are the population related most closely to the Rotinese. Both peoples share similar seeming categories of social organisation. Yet the differences between these categories are profound.

The general term for 'earth', 'land' or 'territory' is rai. As on Roti, the land is oriented with its 'tail' (Tetun: ikun; Rotinese: iko-k) to the west and its 'head' (Tetun: ulun; Rotinese: langa-k) to the east. Another term used among the Tetun is rae. (This is the term that relates - by sound change of $r>d$ - to the Rotinese for earth, dae.) The term rae among the Tetun is most often used in opposition to the (directional) term for sea, lor. In the coastal Tetun cosmology, north is the rae ulun ('head land'); south is lor ain ('foot land'). On its own, rae has the sense of (uncultivated) 'land', rather than 'earth'.

Within this scheme, Wehali is the rai hun, leo hun: 'Land of origin, leo of origin.' The critical term here is leo. Whereas among the Rotinese, a leo is a clan-like origin group defined by its position within a particular nusak or domain and thereby confined to that nusak, a leo among the population of Wehali is a named residential group - a hamlet - comprised of specific named houses. Just as Wehali is the source and centre of the whole population, the houses in the named hamlets surrounding the central hamlet of Wehali are the origin of individual members of society. Houses and the land associated with them are inherited by the eldest of a group of sisters in each generation. Thus continuity is maintained at the centre, whose purpose has long been to export its population, particularly its male population.

Inner Wehali's formal structure consists of four hamlets (leo) around a single central hamlet known as Laran, 'centre'. Within this centre, however, is an inner 
complexity of 12 named houses (uma). (See Therik 2004 for a remarkable study of the domain of Wehali.)

\section{Contemplating Categories: Comparisons of 'Male' and 'Female'}

At its centre, in Wehali, was the Nai Kukun, 'The Dark Lord', who represented the earth. He was 'The One who eats reclining, who drinks reclining' (mahaa toba/mahemu toba). He was also known as 'The Female Lord' and as a representative of the female attributes of the Earth. As such, he was - as is everything in Wehali- 'feminised'. In contrast with this 'Dark Lord' was the lord who spoke and acted on behalf of this shrouded, silent presence. This speaking lord was referred to as the Nai Roman, 'The Visible Lord'. In historical terms, this figure was the Liurai of Wewiku. As Liu-Rai, this personage stood visibly 'above the earth', as 'male' (mane) on the 'periphery' (molin) of Wehali. This idiom is capable of continual, recursive extension: the Liurai, in turn, could be seen as 'centre' and 'female' in relation to the next sphere of rule, which was 'male' and 'exterior'.

Wehali is a totally matrilineal area: all land, all property, all houses belong to women and are passed from one generation of women to the next. In contrast, most other Timorese societies (including other Tetun groups as well as the Rotinese and Atoni) are patrilineal in political orientation (although not necessarily in their total social organisation). In Wehali, men are exchanged as husbands in marriage, never women. And in legend as in reality, Wehali is the 'husband-giver' to other areas of Timor. Thus, whereas Wehali traces its origins within its sphere exclusively through women, surrounding realms trace their relations of origin through males, some of whom are said to have come from Wehali. The founder of the Sonba'i Dynasty among the Atoni peoples, for example, is recognised as having come as a lone male from Wehali.

In terms of the comparisons set out for discussion in this paper, Rai Wehali is conceived as the centre of Timor (Rai Timor) and of the Earth itself (Rai Klaran). It is a 'female' centre and extends without limit. As a centre, it represents the Earth itself. By comparison, the domains of the Rotinese and Timorese are bounded entities. The ruler of Amanuban, for example, held the title of 'he who enclosed the land'. In contrast with Wehali, Termanu-and all the other nusak on Roti-are 'male' centred domains. The lord or lords concerned with the rituals of the earth are subordinate to the ruling male power of the domain. Amanuban - and other Atoni domains - are a curious halfway house. Amanuban's formal structure is like that of Wehali: a central lord with four protecting lords, then four warrior lords. But Amanuban's central lord displaced earlier lords of the earth and was distinctively 'male'. However, once installed as ruler within a structure that implied (indeed required) a female centre, the authority of that 
ruler was 'feminised' and the rulers around him took on evident formal male characteristics as guardians of the centre.

It is interesting that the Tetun term for 'settlement' or 'village' outside Wehali is knua ( $>^{*}$ banua). Wehali has no knua. The term knua, however, is used for Wehali in a specific metaphoric sense. In this sense, it refers to the 'sheath' of a sword. Wehali is that 'sheath'. In regard to Wehali, it is said, Mola isin e mela knuan: 'Take the sword but leave the sheath.' According to the Wehali view of itself, as a centre, it can only give; it can never take. As permanent 'giver', Wehali cannot be subordinate. Hence in Timor there is only one polity like Wehali.

\section{Conclusions}

Comparison is the critical task of anthropology. A controlled comparison sets forth as precisely as possible the framework within which a particular comparative effort is undertaken. In this paper, the general framework has been provided within a comparative Austronesian context but with a specific focus on three linguistically distinct cultural groups - the Rotinese, the Atoni Pah Meto and the Tetun - in the Timor area of eastern Indonesia. The concern has been with each cultural group's categorical conception of land and territory and how these categories are defined within specific historically formed, ritually defined, (state-like) structures - Termanu, Amanuban and Wehali.

Such comparisons lead to wider issues fundamental to each of these societies - ideas of rule and authority, of precedence and derivation, of encompassed and encompassing, of subordination and superordination-all linked intimately to conceptions of 'male' and 'female'. Each of these societies possesses its own variant understanding of the world and has articulated this understanding within specific, historically bound, socially constructed polities. Comparison allows us to appreciate how these various articulations relate to one another and how they may relate to other Austronesian societies.

Based on present linguistic and archaeological evidence, it would appear that Austronesian-speaking populations have been on Timor for more than 4,000 years. Timor, as a rich source of precious aromatic sandalwood, has been the target for long-distance traders for at least 1,000 years (see de Roever 2002) and its populations have been subjected to European influences for more than 500 years. These factors - a long-resident population that has had time to differentiate and to settle the diverse environments of a relatively large island, that has been open to a steady flow of trade goods including weapons, seeds and tools and that, as a result, has been able to develop and elaborate a variety of related, yet competing polities - have given the Timor area a distinctive cultural signature within the wider Austronesian-speaking world. 
Similar configurations of categories and ideas define the Timor area in ways that can be seen to differentiate Timor from other parts of eastern Indonesia and, more broadly, from other parts of the Austronesian world. At the same time, many of the basic categories on which these configurations are constructed are common (or at least similar) throughout the Austronesian-speaking world. Perhaps it is only when we have clearly defined the categories of one area of the Austronesian world and come to understand their historical variation that we can move on confidently to wider comparisons.

\section{References}

de Roever, Arend. 2002. De jacht op Sandelhout: De VOC en de tweedeling van Timor in de Seventiende Eeuw. Proefschrift: Leiden University.

Fox, James J. 1971. 'A Rotinese dynastic genealogy: structure and event.' In T.O. Beidelman (ed.), The Translation of Culture, London: Tavistock. pp. 37-77.

Fox, James J. 1979a. 'A tale of two states: ecology and the political economy of inequality on the island of Roti.' In P. Burnham and R.F. Ellen (eds), Social and Ecological Systems, London: Academic Press. pp. 19-42.

Fox, James J. 1979b. 'Standing in time and place: the structure of Rotinese historical narratives.' In A. Reid and D. Marr (eds), Perceptions of the Past in Southeast Asia, No. 4, Kuala Lumpur: Heinemann Educational Books (Asia) Ltd. pp. 10-25.

Fox, James J. 1980a. 'Introduction.' In J.J. Fox (ed.), The Flow of Life: Essays on Eastern Indonesia, Cambridge (Mass.): Harvard University Press. pp. 118.

Fox, James J. 1980b. 'Obligation and alliance: State structure and moiety organisation in Thie, Roti.' In J.J. Fox (ed.), The Flow of Life: Essays on Eastern Indonesia, Cambridge (Mass.): Harvard University Press. pp. 98-133.

Fox, James J. 1983. 'The Great Lord rests at the centre: The paradox of powerlessness in European-Timorese relations.' Canberra Anthropology, 5 (2). pp. 22-33.

Fox, James J. 1988a. To Speak in Pairs: Essays on the Ritual Languages of Eastern Indonesia. Cambridge: Cambridge University Press.

Fox, James J. 1988. 'Historical consequences of changing patterns of livelihood on Timor.' In D. Wade-Marshall and P. Loveday (eds), Northern Australia: Progress Prospects (Vol. 1: Contemporary Issues in Development), Canberra: Research School of Pacific Studies, The Australian National University. pp. 259-79. 
Fox, James J. 1995. 'Installing the "Outsider" Inside: The Exploration of an Epistemic Austronesian Cultural Theme and its Social Significance.' First Conference of the European Association for Southeast Asian Studies, Leiden University.

Fox, James J. 1999. 'Precedence in Practice among the Atoni Pah Meto of Timor.' In L.V. Aragon and S. Russell (eds), Structuralism's Transformations: Order and Revisions in Indonesia and Malaysia, Tucson (Ariz.): Center for Southeast Asian Studies, Arizona State University. pp. 1-36.

Fox, James J. In press a. 'Traditional Justice and the "Court System" of the Island of Roti.' In Dionisio Babo Soares et al (eds), Traditional Justice and Conflict Resolution in Timor, Asia Society.

Fox, James J. In press b. 'The discourse and practice of precedence.' In Michael Vischer (ed.), Precedence, Canberra: Research School of Pacific and Asian Studies, The Australian National University.

McWilliam, Andrew 1989. 'Narrating the Gate and the Path: Place and Precedence in South West Timor.' Unpublished PhD thesis, The Australian National University.

Parera, A.D.M. 1971. Sedjarah politik pemerintahan asli di Timor. Kupang: University of Nusa Cendana.

Sahlins, Marshall. 1985. 'The stranger-king; or Dumezil among the Fijians.' In M. Sahlins, Islands of History, Chicago: the University of Chicago Press. pp 73-103.

Schulte-Nordholt, H.G. 1971. 'The Political System of the Atoni of Timor.' Verhandelingen van het Koninklijk Instituut voor Taal-, Land-en Volkenkunde, No. 60. The Hague: Martinus Nijhoff.

Therik, Gerzon Tom. 2004. Wehali: The Four Corner Land: Traditions of a Timorese Ritual Centre. Canberra: The Australian National University.

\section{ENDNOTES}

${ }^{1}$ For at least two decades, I have been engaged with colleagues and students in the comparative study of the societies of eastern Indonesia (see Fox 1980a for an early formulation of this comparative project). Approximately a decade later, through the Comparative Austronesian Studies Project initiated in the Research School of Pacific and Asian Studies, these comparative interests in eastern Indonesia became subsumed within a wider comparative framework. This framework offers a perspective on what may be considered the distinctive features of the societies of eastern Indonesia and on how they relate to the wider Austronesian-speaking world. From the outset, this comparative study has focused on cultural categories, their 'metaphoric' elaboration and their social expression. An array of common Austronesian categories provides a 'starting point' for a combination of cultural and social analysis. Insofar as it relies on the evidence of historical linguistics to provide an initial defining point, this kind of analysis is essentially historical.

2 Since the early 1980s, researchers have focused on the 'house' (uma, soa, fada) as a key social and symbolic component in the structuring of the societies of eastern Indonesia (Fox 1980a: 10-12). Equally important in the analysis of eastern Indonesian societies has been the focus on 'clans' as 'origin groups' represented, in various ways, by their constituent 'houses'. The particular problematic concern of this 
comparative examination will be on the relationship between 'origin groups', the house or houses that represent them, and the territory they occupy.

3 Eastern Indonesia is an area of early European contact and historical records offer considerable, often detailed, accounts of local developments. In some cases, these records date back to the 16th and 17th centuries; in others, the records begin only in the 19th or as late as the early 20th century. Generally, as these records become particularly informative, they signal a transformation in local societies as a result of the European encounter. It is often possible to chart these transformations: the coalescence of groups, the rearrangement of relations among territorial entities, the creation of polities and the beginnings of an administrative structure. These changes are of direct relevance to concepts of 'land', 'territory' and 'domain'. In eastern Indonesia, history looms large in another sense. Virtually all of the societies of the region maintain accounts of the past. These narratives are called on to explain, confirm and justify relations among groups within specific territories. Some recount the formation of the land, others the journeys of the ancestors and their arrivals, the founding of domains and the development of relations within them. I have referred to these narratives and the accompanying commentaries, together with the implicit rules by which these narratives are utilised as 'origin structures'. They present an image of the past and define precedence in the present. To gain an understanding of local ideas of land and territory, it is necessary to locate these fundamental categories within their particular 'origin structures'.

4 I have already written various accounts of the domain of Termanu (see Fox 1971 on the dynastic genealogy of the domain; Fox 1979b on its historical narratives; and Fox In press b. on the order of precedence among origin groups established by the combination of genealogy and narrative). Here I wish merely to sketch an outline of the domain and its historical narratives for purposes of comparison. 